8. Макогоненко М. Використання інформаційних технологій навчання в практиці роботи вчителя. Збірник наукових праць. Частина 4. 2012. - С. 230-236.

9. Полонский В. М. Инновации в образовании (методологический анализ) // Инновации в образовании. 2007. №3. - С. 68.

10. Сорочан Т. М. Професійний розвиток педагога Нової української школи в умовах формальної і неформальної освіти: збірник спецкурсів / Авторський колектив. Київ: Агроосвіта, 2018.

11. Уруський В. І. Формування готовності вчителів до інноваційної діяльності: Методичний посібник. - Тернопіль: ТОКІППО. 2005. - С. 96.

12. Чумак О. В. Інноваційна діяльність як чинник розвитку суспільства в умовах глобалізації: дис. на здобуття наукового ступеня канд. філософ. наук: 09.00.03. Запоріжжя, 2015. - С. 196.

DOI https://doi.org/10.30525/978-9934-26-173-2-34

\title{
ЗАПРОВАДЖЕННЯ ІНТЕРАКТИВНИХ ЗАСОБІВ У ВИКЛАДАННІ КЛІНІЧНИХ ДИСЦИПЛІН В СУЧАСНИХ УМОВАХ ПАНДЕМІЇ COVID-19
}

\section{Харченко Ю. П.}

доктор медичних наук, професор, завідувач кафедри дитячих інфекційних хвороб Одеський начіональний медичний університет

Юрченко І. В. кандидат медичних наук, доцент кафедри дитячих інфекційних хвороб Одеський національний медичний університет

Зарецька А. В.

асистент кафедри дитячих інфекиійних хвороб, доктор філософії Одеський начіональний медичний університет м. Одеса, Украӥна

В умовах постійних спалахів інфекційних хвороб, завдяки розвиненій транспортній галузі, з кожним роком все більше підвищується попит на лікарів компетентних 3 діагностики та лікування інфекційних хвороб. 
В 2019 році в світі вперше заговорили про нову хворобу COVID-19, а вже на початку 2020 р. всі сфери сучасного життя довелося адаптувати під умови карантинних заходів. Вища освіта не стала виключенням, i попри моральну та професійну неготовність викладачів, освітній процес розпочав свою трансформацію.

Метою діяльності вищого навчального закладу в умовах пандемії постає забезпечення відповідності рівня освіти та збереження іiї якості.

Освіта лікарів $є$ унікальною, вона потребує постійного самовдосконалення, і для якісного, всебічного засвоєння предмету недостатньо оволодіти лише теоретичним матеріалом. Ще в XVII столітті відомий чеський педагог Ян Амос Коменський зазначав: «Варто було б починати навчання не $з$ усного трактування речей, а з реального за ними спостереження. I тільки після ознайомлення з самим предметом приступати до висловлювання про нього, з'ясовуючи більш всебічно... Якщо іноді наочно немає предметів, то замість них можна застосовувати копії або зображення, спеціально заготовленні для навчання» [1, с. 140].

Відповідно до даних літератури, близько 14\% студентів здатні самостійно ефективно засвоювати текстову інформацію. У зв'язку з цим, залишається актуальним пошук та імплементація нових методів навчання [2, с. 147$]$.

Підготовка медичних спеціалістів є специфічним процесом, який включає не тільки отримання глибоких знань, але й можливість їх реалізації у вигляді виконання певних професійних лікувальних дій. Важливим стає вміння приймати конкретне, а часто нестандартне рішення у певних клінічних ситуаціях.

При підготовці майбутніх лікарів на клінічній кафедрі, невід'ємною складовою $\epsilon$ безпосереднє спілкування 3 профільним пацієнтом в стаціонарі (збирання анамнезу та огляд) 3 отриманням навичок адекватної оцінки стану хворого.

Однією з найбільших труднощів для студентів старших курсів під час проходження практичних занять на клінічних кафедрах $є$ курація пацієнта. Самостійна робота з пацієнтом, а саме: вміння зібрати скарги, 3'ясувати анамнез хвороби і життя хворої дитини, огляд та обстеження за системами органів, виявлення ведучих патологічних симптомів та синдромів, оцінювання отриманих лабораторних і інструментальних даних - сприяє розвитку самостійного клінічного мислення.

Отримання студентами компетентностей пов'язаних 3 клінічною роботою, перш за все в інфекційному стаціонарі, має свої особливості, які визначаються етіологічними, епідеміологічними, патогенетичними властивостями хвороб, а також їх циклічністю та контагіозністю [3, с. 112]. Проте, в умовах COVID-19 будь-який контакт 3 пацієнтами 
може нести небезпеку як для хворого так і для студентів. Таким чином, навчання на клінічній базі дитячих інфекційних хвороб само по собі несе ризик для студентів при отриманні навичок «біля ліжка хворого», a небезпека інфікування COVID-19 робить це неможливим. Перш за все, для забезпечення безпечного навчання студентів, найвагомішим інструментом є своєчасна вакцинація як COVID-19, так сезонного грипу та інших керованих інфекцій.

Окрім того, вагомим важелем залишається імплементація в навчальний процес епідемічної «обізнаності» та «тренування».

Поняття «обізнаність», в першу чергу, включається наявність у студентів фундаментальних знань стосовно етіології, механізму та шляхів передачі захворювання, тривалості інкубаційного періоду, тривалості заразності пацієнта та якостей збудника (стійкість в оточуючому середовищі, методи знешкодження).

Під поняттям «тренування» підлягає відпрацювання навичок одягання захисного медичного спорядження (маска, шапка, медичні рукавички, та за необхідності окуляри та фартух), його правильне знімання після використання, гігієнічна обробка рук та засвоєння правил входу до палати/боксу та перебування в середині.

Поряд із тим, труднощі навчання біля ліжка хворої дитини викликають необхідність розробки навчальних робочих програм, методичних розробок із застосуванням на практичних заняттях сучасних комп'ютерних технологій. Наприклад «віртуальний хворий» 3 певними ознаками хвороби або за допомогою комп'ютерної графіки деталізація елементів висипу на шкірі чи слизових оболонках. Такий підхід дозволить підвищити рівень оволодіння практичними навичками студентів та підвищити їх рейтинговий рівень, сприяє їх конкурентоспроможності серед випускників.

Впровадження в навчальний процес інтерактивних методик викладання, з використанням відеоматеріалів, ілюстрованих лекцій, власних тематичних фотоматеріалів, ситуаційних задач $\epsilon$ важливим інструментом в досягненні всебічного розвитку та навчання студентів старших курсів, в тому числі на кафедрі дитячих інфекційних хвороб.

Так, використання ілюстрованих лекцій з відео- та фотоматеріалами, ситуаційних задач з використанням фото, аудіо-та відеоряду, дає можливість в отриманні про більшість нозологічних форм наочної інформації з якими майбутні в своїй професійній діяльності можуть зітнутись студенти незалежно від епідемічного сезону, поширеності хвороби та присутності на лікуванні у клінічних відділеннях інфекційних хворих саме в цей час.

Практика впровадження методики «перегорнутого навчання», в системі сучасної української освіти, стає незамінною. Сутність їі полягає 
у вивченні теоретичного матеріалу після чого необхідно виконати вдома завдання на закріплення отриманих напередодні, на практичних та семінарських занять, знань [2, с. 147-148].

При такій системі навчання, робота в аудиторії покликана на обговорення тих моментів, з якими виникли у студентів труднощі при підготовці, та відпрацювання навиків відповідно помилок, які допущені студентом, $з$ подальшим закріпленням матеріалу на практичному занятті з використанням клінічних ситуаційних задач («сase study»).

Навчання за методикою «перегорнутого навчання» не тільки залучає студентів до усвідомленої самостійної підготовки, але й підвищує в них впевненість в прийнятті самостійних рішень при виконанні завдань.

Важливим елементом контролю навчання $\epsilon$ рішення тематичних клінічних ситуаційних задач. Така робота викликає у студента потяг до клінічного логічного мислення, пізнавальної активності, сприяє знаходженню єдиного вірного рішення. Ситуаційні задачі це модель типової або атипової клінічної ситуації, де об'єктом досліджень є хвора людина. Ïї необхідно обстежити, виявити ведучі патологічні синдроми, провести диференційну діагностику та обрати відповідне лікування за результатами лабораторно-інструментальних досліджень і клінічної картини.

\section{Висновки.}

Таким чином, впровадження інтерактивних засобів, дозволяє розширити можливості прикладного викладання клінічних дисциплін, більш якісного засвоєння навчального матеріалу та сприяє підвищенню у студентів самостійності в прийнятті клінічних рішень.

\section{Література:}

1. Балычевцева И.В., Самойленко И.Г., Чернышева О.Е. и др. Учебные видеофильмы как интерактивный компонент обучения на кафедре педиатрии, неонатологии и детских инфекций Донецкого национального медицинского университета. Здоровье ребёнка. 2018. Том 13. № 3. С. 140-142.

2. Боярская Л.Н., Корниенко Г.В., Дмитряков В.А. Интерактивные методы обучения врачей-интернов - детских хирургов в Запорожском государственном медицинском университете. Современная педиатрия. 2017. № 5 (85). С. 147-149.

3. Сороханд В.Д., Сидорчук А.С. Оптимізація навчального процесу і клінічної курації профільних хворих іноземними студентами на кафедрі інфекційних хвороб та епідеміології ВДНЗ України «Буковинський державний медичний університет». Актуальная инфектология. 2016. № 2 (11). С. 112-113. 